stoichiometry. I hadn't previously thought of applying stoichiometric principles at subcellular or planetary levels, and frankly, after reading about them, I don't think I want to know more. I had also not previously seen the term 'stoichiometry' applied to the coupling of biogeochemical cycles except in connection with limiting nutrients; of course, it fits perfectly.

Few, if any, details of stoichiometry seem to have been overlooked by Sterner and Elser, and their book will be a useful reference tome for many years to come. However, the completeness of the book is also its Achilles' heel. Because of its complexity, I would not give this book to undergraduate ecologists to introduce them to the impor- tance of stoichiometry. It is a treatise, not a textbook, and represents a massive amount of work.

The hundreds of references in the bibliography are worth the price of the book alone. I would have liked to see a backreferencing system, adding after each reference the page numbers where it is discussed in the text. Such a feature has helped G. E. Hutchinson's Treatise on Limnology endure for many decades. Also, the index could be improved; for example, 'trophic cascade' doesn't appear in the index, despite being discussed several times in the book and being one of the most important areas where stoichiometry has enlightened modern ecology.

The proliferation of books costing
US $\$ 100$ or more has made it almost impossible for most libraries or scientists to buy more than a small proportion of them. This book is a refreshing exception. It is well edited (although I did find a couple of typographical errors), and figures and tables are clearly reproduced, although there are no photographs. Yet it has a price of only $\$ 29.95$. If future authors want their books to be widely read, they should pay attention to these features. All in all, I consider the book a 'must have' for ecologists, limnologists and biogeochemists, and it is an important reference work for others in the Earth sciences. David W. Schindler is in the Department of Biological Sciences, University of Alberta, Edmonton, Alberta, T6G 2E9, Canada.

\title{
Behind the wall
}

\section{Hans Neubert's murals paint a picture of scientific research in East Germany in the 1950s.}

\section{Alison Abbott}

In 1961, when German artist Hans Neubert was 30 years old, he jumped one of the last trains to west Berlin before the Berlin Wall shot up and sealed so many fates. He left behind in his native Dresden, seemingly forever, a vast number of portraits and landscapes.

He also left behind an extraordinary cycle of ten oil-on-canvas wall paintings at the Friedrich Löffler Institute, now the Federal Research Centre

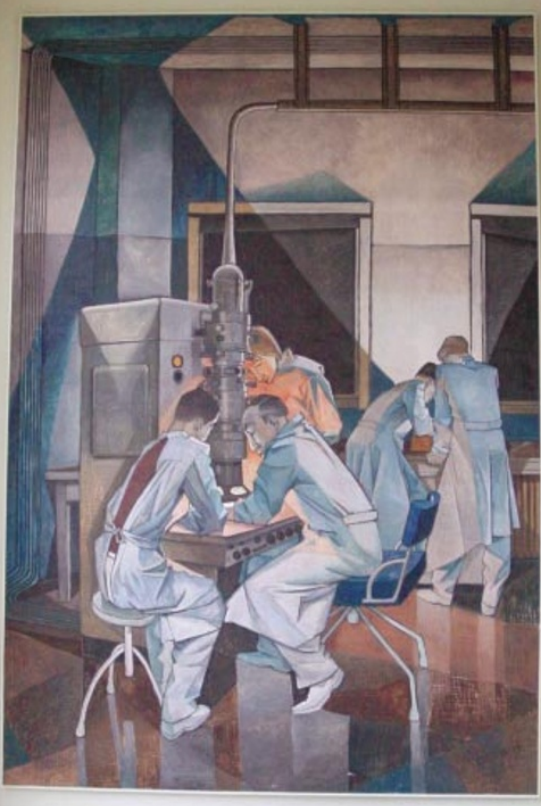

Free speech: Hans Neubert encouraged scientists to discuss the accuracy of his paintings. for Virus Diseases of Animals at Insel Riems, a remote Baltic island north of Greifswald in eastern Germany. Löffler, famous for his 1898 discovery of viruses, founded the institute in 1910, and Neubert's cycle was officially unveiled at its 50th anniversary.

Neubert painted the cycle between 1957 and 1960, when Heinz Röhrer was the director of the institute. Röhrer had initially engaged Neubert to paint his family's portrait, but scientist and artist became fascinated by each other's work. Röhrer let Neubert watch, and sketch, one of his earlymorning autopsies of a cow, and the idea emerged of a large painting of the scene for the foyer of the institute's main building. Such was its success that Röhrer commissioned the entire cycle, which now covers the foyer, winds up the stairs and finishes in the gallery on the first floor. Neubert's brief was to depict the full range of the institute's scientific work, from taking blood from rabbits to collecting antibodies, and, as shown here, searching for viral particles by electron microscopy.

A devotee of Rembrandt and Titian, Neubert also absorbed more contemporary influences such as realism and expressionism. Precision was second only to composition in Neubert's priorities. He set up an atelier in the spacious entrance hall of the 1940 building and shrouded it with huge white sheets. Neubert encouraged the scientists to visit him at work to discuss the progress and accuracy of his paintings. Older scientists at the institute still remember his struggle to understand exactly how a hand must be placed to make an injection or to draw blood. The result is a social record at many different levels, as well as an artistic gem of its era.

The only clear deviation from scientific reality occurs in the painting shown here of electron microscopists at work - this 1945 electron microscope would have operated in the dark. But Neubert includes two assistants examining electron micrographs on a light box in the far side of the room. Complementary triangles of different-coloured light illuminate the faces of each of the five figures and cast long reflections into the floor. The electron microscope, manufactured by Siemens, was one of only two imported into East Germany, and was a source of immense pride to the institute's scientists. At some 4.6 metres high, the painting reflects the instrument's scale and the intensity of the grouped figures.

Artistic realism didn't necessarily equate to political realism, however, and when the cycle was close to completion, Röhrer needed to have them approved by the East German authorities. The paintings were not subversive: they simply celebrated science. But they did not explicitly celebrate the value of that science for the people, as the authorities expected. So Neubert provided a few drafts of a supposed grande finale, in which smiling peasants watched scientists vaccinating farm animals. "These pleased the authorities, who were then happy to give approval," recalls Neubert. Approval assured, Neubert destroyed the drafts and painted the final theme that had always interested him: an international group of scientists gathered at the institute to exchange ideas and argue their theories. The 50th anniversary in fact provided exactly such an occasion.

When the Berlin Wall came down in 1989, there were calls for the paintings to be destroyed by those who equated Neubert's style with social realism, a construct associated with the Communist regime. But many fought for their preservation. In 1993, Neubert, by now a contented landscape, still-life and portrait painter in Bavaria, visited Riems again with his wife Barbara, the west Berliner for whom he had risked so much more than 30 years before. He was relieved to find that the colours had held firm against the damp air. Thanks to the protection of the scientists at Riems, Neubert's brief interaction with science has proved equally long lasting.

Alison Abbott is Nature's senior European correspondent. 